\title{
THE SOCIAL ASPECT OF THE USAGE OF PUPILS' SELF-EXPRESSION SKILLS ACQUIRED WITHIN MUSIC EDUCATION
}

\author{
IVETA KEPULE \\ Rezekne Academy of Technologies \\ Atbrīvošanas aleja 115, Rezekne, Latvia \\ E-mail address: kepule.iveta@gmail.com \\ https://orcid.org/0000-0003-3275-2621 \\ AINA STRODE \\ Rezekne Academy of Technologies \\ Atbrīvošanas aleja 115, Rezekne, Latvia \\ E-mail address: aina.strode@rta.lv \\ https://orcid.org/0000-0001-9702-5834
}

\begin{abstract}
Aim. The aim of the research is to study the usage of primary school pupils' self-expression skills acquired within music education in various social contexts.

Methods. Theoretical research method - the analysis of literature, empirical data acquisition method - questionnaire. Statistical data processing has been carried out in IBM SPSS 23 programme, using the following data processing methods: frequency analysis; Mann-Whitney $U$ test for the comparison of two independent groups; Kruskal-Wallis test for the comparison of three or more independent groups; Kendall rank correlation coefficient for the assessment of associations between two variables.

Results. In the development of self-expression skills, an important aspect is the social performance criterion that is based on pupils' need for self-expression in a social environment of practising music. Age and gender-based correlations in the assessment of a self-expression skill criterion "Social performance" indicate that with age pupils become more independent and engaged in music-related social activities. Girls are socially more active and emotional and engage in artistic activities more often. The research confirms the role of teachers in the development of pupils' self-expression skills, promoting integration of formal and informal learning process and transformation in formal and informal learning environment.

Conclusions. The dynamics and interactions of self-expression skills' development factors (social, emotional and intellectual) defines pupils' individual self-expression skills and development tendencies. Self-expression is important for pupils in social aspect, as it is related to socialisation in microenvironment (family) and macroenvironment (friends) and affects cooperation and communication.
\end{abstract}


Key words: social environment, self-expression skills, music education, primary school, questionnaires.

\section{INTRODUCTION}

$\mathrm{T}_{\mathrm{t}}$ oday's education includes three general thematic areas: science, art and technology. Thus, it promotes the development of pupils in artistic and scientific aspects, considering that knowledge and pupils' identity are inseparable (Barrett, 2011). This vision suggests a multidisciplinary approach to music education, considering that no learning situations are socially neutral.

Self-expression is related to a process, in which a pupil effectively uses knowledge, skills and attitude, necessary to control emotions, to set and achieve goals, to maintain positive relationships and to make responsible decisions. Different culture modelling perspectives on self-expression highlight the main purpose of today's education - to reveal the individuality of each pupil. This indicates that self-expression issues in the education process are topical, simultaneously proving the complexity and the need for research regarding this matter.

Rapid globalisation creates a situation, in which music education promotes social integration, giving a more prominent role to media, and thus highlighting the value of self-expression skills in circumstances surrounding changing social situations. There is a rapid establishment of a connection between music as social belonging and increasing cultural diversity, stemming from ethnic, linguistic, religious, socio-economical and educational differences, raising the adaptive value of the culture of music (Cross, 2001; Huron, 2001). Pavlou (2019) associated inclusion of media in music education with socialisation as a modern-day dominating communication culture that defines a pupil's musical interests, including self-expression. Meeting self-expression needs indicates social acceptance, which can be regarded as a stimulus for the development of self-expression skills.

In order for primary school pupils to feel the need for self-expression in music education and acquire self-expression skills, teachers should consider the relationship between a pupil's musical self-expression experience and interactions in family, school, society, which in turn affect the learning process and promote the development of qualitative self-expression skills.

In reality, the discourse between the results defined to be achieved in music education, a pupil's self-expression in music education and his musical experience is observed. It is advised that the self-expression experience should be associated with the individual's development tasks, because only such experience, which encompasses knowledge and understanding, physical, mental and social skills, intellectual and emotional activity, forms a base for personal progress (Žogla, 2001:170) and requires self-expression in practical activities, highlighting the significance of "I/self" system in the educational process. 
Music education affects the personality development progress, which is necessary to gain achievements in school and beyond it in the long term, including the pupil's self-expression skills, which integrate learning in school with out-of-school activities and social environment in general. Perception, understanding and interpretation of music is related to intelligence and the body. Therefore, it has inductive meaning, which is based on innate abilities, acquired knowledge and skills and social attitude (Reybrouck, Eerola, \& Podlipniak, 2018).

Non-traditional music teaching practice using transformation of the acquired knowledge and skills, based on pupil's individual needs, interests and abilities, promotes self-expression, pupil's responsibility, independence, extra-curricular learning experiences and inclusion in society, creating actual changes for meeting pupils' needs for self-expression.

The research problem is defined by the correlation between pupils musical practice experience in school and out-of-school activities, which do not sufficiently promote the real-life realization of pupils' individuality and expression of interests that are related to pupils and reflect pupils' extra-curricular interests, self-expression in social life, demonstrating acquired knowledge and understanding.

\section{THE DEVELOPMENT OF SELF-EXPRESSION SKILLS IN SOCIAL ENVIRONMENT}

The development of self-expression skills depends on a social environment, in which it takes place and communication, which in this environment is regarded as a standard. The relationship between a pupil and environment affects personality traits, including the development of self-expression skills (Shanker, \& Bertrand, 2013; Siegel, 2010).

Interaction takes place both in micro and macro environment. Rogers (1969) claims that any social environment consists of three components:

- cognitive (knowledge and perception of oneself as an object), which indicates deliberate and targeted use of ones' own knowledge and abilities for self-expression;

- emotional (positive or negative experience in attitude towards oneself as an object), which indicates self-assessment of self-expression experience.

- behavioural (readiness to act), which, by mutual integration, promotes pupils' awareness, forms socially-emotional domain, searching for self-expression opportunities.

The pupil's family is important for the development of self-expression skills - upbringing, family values and traditions, system of attitudes in family. Initially, the pupil learns, using parent-child, child-child relationships. When family values do not match with musical education objectives, the pupil has low motivation to take up activities in music education, has negative attitude towards musical activities, which do not promote the development of self-expression skills. 
From the perspective of psycho-emotional development of "I", the pupil's identification, for instance, with parents and teachers, continues throughout the primary school years (Vuorinens, \& Tūnala, 1999). It is a microenvironment, where pupil's roles and interpersonal relationships stimulate or hinder involvement in stable, gradually more complex relationships with environment and its activities (Bronfenbrenner, 1994).

The pupils' need for interaction with their closest family members is gradually oriented to schoolmates (mesoenvironment), as the need for inclusion in a group of friends arises. Baacke (1983) assesses friends as the most significant establishers of socialisation and experience outside the family during learning and leisure time. Pupils need to express themselves in order to feel belonging to his class and group of friends. It means that the environment is significant in the learning process. New social contacts affect the perception of oneself, as pupils actively analyse themselves and compare themselves to others (Burdjē, 2004; Svence, 1999).

Macroenvironment is a comprehensible model of micro- and mesoenvironment, characteristic to a certain culture (Bronfenbrenner, 1994). This raises the question of what culture-related musical skills promote self-expression, based on music education goals and socio-cultural features (Howard, 2018).

In general, social environment dynamics are defined by social processes, affected not only by an individual's traits, but also by socio-cultural traits of a society over a long time period. Although the effect of social environment on a pupil is, to a certain degree, irregular, it is formed in a targeted way, according to pupil's "I" structure, and is related to the level of school achievements in different areas of activity. Growing up, a pupil expands his social relationships, becomes aware of increasing social environment (micro-, mezo-, macro), which indirectly affects one's self-expression skills (Fig.1).

It can be concluded that self-expres-

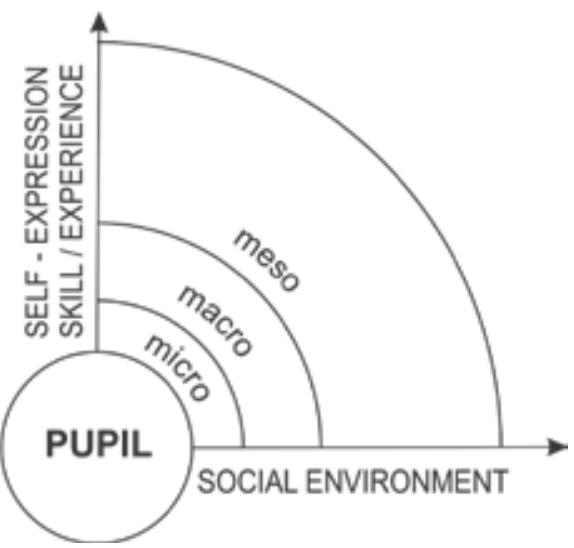

Figure 1

Development of self-expression skills in social environment.

Source: own research sion skills are developed through the relationships of a person with an environment. In this process, it is essential to predict cultural development tendencies of a society and to be aware of the importance of self-expression in its social aspect, where various concepts and notions can be perceived differently or not understood at all (Bruner, 1996). Pupils search for an environment, which allows them to present their skills and express attitude. Self-expression experience is defined by an individual's personality, which is significant for the presentation of the pupil's " $\mathrm{I}$ " system, as it 
defines that pupils' personal significance in this system, therefore increasing or weakening the need for self-expression in the society (Hall, \& Lamont, 2009).

In the $21^{\text {st }}$ century, achievements in science and technology and their use in the pedagogical process and on a daily basis, raise the need to analyse the impact of virtual environment on the process of self-expression skills' development. Previous studies (Spanhel, 2006; Rubene, 2011) show that primary school pupils tend to spend increasingly more time communicating in a virtual environment, without the presence of adults, brothers, sisters and peers, which indicates the increasing significance of the virtual environment in interaction, diminishing the role of parents and teachers in pupil's socialisation and fundamentally changing the perception of the model of person's mutual relations (Schorb, 2005). Social surrogacy hypothesis assumes that a pupil can use "temporary social surrogates", if direct social interaction is not possible (Schäfer, \& Eerola, 2018). Self-expression in music can be a "temporary surrogate" for interaction in the virtual environment or, using identification processes, the example of self-expression skills can become a motive for the stimulation of self-expression need for other pupils, including the conscious use of produced information and/or producing of one's own vision (Baacke, 2007).

Assuming that the environment (initially microenvironment, then mesoenvironment and macroenvironment) is an important prerequisite for pupils' socialisation, music education as a promoter of self-expression skills is oriented towards a pupil's impression formation and wish to perform or cooperate, using the information in a virtual environment (Popers, 2005). Learning objectives in the microenvironment are related to pupils' individuality, yet self-expression skills develop in relationships between microenvironment, mesoenvironment and macroenvironment (Ben-Eliyahu, 2019).

The relationship between a teacher and a primary school age pupil in music education is an important component of communicative culture, which the authors of the research associate with the social aspect of the development of self-expression skills. The relationship is perceived as a pedagogical value that is implemented in activities (music acquisition) and learning forms and methods. Pedagogical process in music education relating to creative activity provides for a relationship: subject-subject (e.g., pupil-teacher or pupil-pupil), in which pupils and teacher engage in equal relationships in creation of knowledge, emotions and cooperation skills. Relationship is successful and sustainable, if learning is based on a certain attitude towards music education. Smits (2000) emphasises that personal interrelations and their quality affect learning, including self-expression skills, which is directly related to self-perception of the subjects.

In the pedagogical process, creating a supporting environment for relationships and dialogue, pupils develop positive activity experience, which promotes creativity, allowing them to select their musical activities and to be confident in their choice. A mandatory condition is the preservation of pupils' experience and broadening of one's own knowledge, supplementing the existent knowledge and experience (Piaget, 1961). Pupils transform the acquired knowledge 
with the aid of personal experience and social views; as a result, motivation and self-assessment is formed, which defines pupils need for self-expression.

On the basis of the analysis of scientific theory, it was concluded that interrelationships of the development of pupils' self-expression skills in social aspects are based on pupils' musical self-expression experience and relationships in family, school and society.

\section{METHODOLOGY}

With the aim to acquire the data on pupils' self-expression experience in music education process and beyond it, a survey was conducted within four respondent groups. 125 pupils and 125 parents, 20 class teacher and music teachers participated in the survey.

The questionnaire is applied to identify, describe and compare opinions of the respondents and attitudes towards the expressions of the studied issues, which are not always directly observable. A characteristic feature of the questionnaire is that the responses to the statements of the questionnaire are provided by people who are directly involved in the studied issue, which allows us to obtain information on the motives and results of the activity (Kristapsone, 2008).

The pupil questionnaire included 30 statements, the parents' questionnaire 25 statements, the class teachers' questionnaire - 25 statements, music teachers' questionnaire -26 statements. The statements related to pupils' education processes in music education, assessing self-expression experience. The respondents assessed the indicator levels of self-expression criteria using a Likert scale (1-4). Self-expression criteria - intellectual, emotional and social, were defined in the prior studies carried out by the authors (Kepule, \& Strode, 2019).

Pupils of $3-5^{\text {th }}$ grade participated in the questionnaire: 68 boys and 57 girls along with the pupils' parents; 4 music teachers and 6 class teachers. The pupils survey took place during music lessons, but the parents of the pupils, class teachers and music teachers filled in the questionnaire in their free time.

The results of the survey are summarised below. The statistical processing of the data was carried out in IBM SPSS 23 programme, using the following data processing methods:

- frequency analysis;

- Mann-Whitney U test for the comparison of two independent groups;

- Kruskal-Wallis test for the comparison of three or more independent groups;

- Kendall rank correlation coefficient for the assessment of association between two variables.

Within the framework of the study, the assessment of self-expression skills criteria "Social activity", "Emotional activity" and "Intellectual activity" have been analysed, and, according to the aim of the study, the indicators of the criterion "Social activity" are analysed in detail. 


\section{RESULTS}

As a result of primary data processing, it has been concluded that the indicators of intensity of musical activity self-expression skills stated in the questionnaire are considered to be significant (more respondents agree than disagree and fully agree with the statement) by $70,1 \%$ of pupils, $74,7 \%$ of parents, $79,8 \%$ of class teachers $81,8 \%$ of music teachers, which confirms the significance of self-expression skills in the development of pupils' personality in the opinion of each group of the respondents within the survey. Music teachers associate the findings with learning process and reflection of their pedagogical skills, but pupils - with anticipated future career, which is not professionally related to music.

The assessment of the indicators of self-expression criteria "Social activity" (69,8\%), "Emotional activity" (76,4\%) and "Intellectual activity" (83,7\%) amongst all groups of the respondents indicate the significance of the criterion "Intellectual activity" in the music learning process and the highest assessment as perceived by the respondents. This indicates the assessment of learning achievements, which reflects educational content acquisition level and is related to the assessment of learning achievement by teachers, is characterised by the use of conceptual knowledge in practical activities.

The criterion "Emotional activity" is highly significant to music teachers $(86 \%)$, as teachers assess pupils' positive attitude towards music practising, which increases learning motivation and brings joy for pupils for performing activities, raises the need for self-expression, but, in pupils' opinion $(65,8 \%)$, assessment partly indicates possible non-compliance of music content to pupil's emotional needs.

The criterion "Social activity" is scored lowest by all the groups of respondents. The assessment from pupils $(64 \%)$ and music teachers $(69,1 \%)$ indicates the use of music knowledge during practical activities in socio-cultural environment, which is understood and applied in both groups of the respondents. However, the parents $(72,7 \%)$ and class teachers $(73,4 \%)$ have assessed social activities higher, which suggests the relation between music education and extra-curricular activities of interest-related education.

Analysing the responses of the participants in general, statistically significant gender-dependant correlations (Tab. 1) have been identified in criteria assessment. Mann-Whitney $U$ test has been applied for the data processing.

Table 1

Criteria assessment for the determination of the gender-dependant correlation

\begin{tabular}{cccc} 
& Emotional action & Intellectual activity & Social activity \\
\hline Pupils & $\mathrm{p}=0.000$ & $\mathrm{p}=0.000$ & $\mathrm{p}=0.000$ \\
\hline Parents & $\mathrm{p}=0.000$ & $\mathrm{p}=0.006$ & $\mathrm{p}=0.000$ \\
\hline Music teachers & $\mathrm{p}=0.000$ & $\mathrm{p}=0.001$ & $\mathrm{p}=0.000$ \\
\hline Class teachers & $\mathrm{p}=0.000$ & $\mathrm{p}=0.004$ & $\mathrm{p}=0.000$ \\
\hline
\end{tabular}

Source: own research 
Analysis of quantitative results of the assessment that varies depending on gender shows maximally significant correlation between all measurement groups $(p=0.000)$ for criteria "Emotional activity" and "Social activity", which can be related to the similarities of the criteria and very significant correlations in the assessment of criterion "Intellectual activity" among the parents ( $p=$ $0.006)$ and class teachers $(p=0.004)$. The correlations in criteria assessment may have arisen because the emotional assessment of pupils' activity often mingles with social activities.

In all the assessments that vary depending on the gender, girls have higher assessment (Mean Rank) than boys. Such correlations may have arisen on the basis of the peculiarities, such as school, the age of the pupils, or as girls are more active and open to art when compared with boys. Girls show interest in self-expression more than boys; they like to perform, express themselves in art subjects, while boys prefer sport activities. The most significant correlation in the assessment of the criterion "Emotional activity" that varies depending on the gender, is observed among the responses of the parents. The highest distribution of the criterion "Emotional activity" is observed among the parents of the girls (Mean Rank 819.91), rather than among the parents of the boys (Mean Rank 640.73). Such correlations may have arisen because the society has a stereotype that boys are not supposed to show their emotions and feelings, while girls are allowed to do so. The parents, based on the stereotype, assess their child and possibly, do not stimulate the expression of emotions.

Kruskal-Wallis $\mathrm{H}$ test has been applied for the determination of correlations for criteria depending on the grade of the pupil (Tab. 2). The assessment of the criterion "Emotional activity" has maximally significant correlations ( $\mathrm{p}$ $=0.000$ ) in all groups of the respondents. Maximally significant correlations $(p=0.000)$ in the assessment of the criterion "Intellectual activity" are observed among pupils, music teachers and class teachers. In the assessment of the criterion "Social activity", maximally significant correlations $(p=0.000)$ are observed among class teachers, and very significant correlations $(p=0.003)$ are observed among the pupils.

Table 2

Criteria assessment for the determination of the grade-dependant correlation

\begin{tabular}{lccc} 
& Emotional action & Intellectual activity & Social activity \\
\hline Pupils & $\mathrm{p}=0,000$ & $\mathrm{p}=0.000$ & $\mathrm{p}=0.003$ \\
\hline Parents & $\mathrm{p}=0.000$ & - & - \\
\hline Music teachers & $\mathrm{p}=0.000$ & $\mathrm{p}=0.000$ & - \\
\hline Class teachers & $\mathrm{p}=0.000$ & $\mathrm{p}=0.000$ & $\mathrm{p}=0.000$ \\
\hline
\end{tabular}

Source: own research

Analysing the assessment of the criteria by pupils and their parents for the determination of correlations depending on the grade, it is observed that Mean Rank dynamics regarding all criteria are negative. Such correlations in the criterion "Emotional activity" assessment depending on the grade may have 
arisen because pupils grow older, learn to control their emotions better, and are too shy to show their " $\mathrm{I}$ ". The correlations in the assessment of the criterion "Social activity" depending on the grade may have arisen because pupils now tend to have versatile interests. Pupils become independent, make decisions on activities to engage in and express themselves in various ways.

Analysing the assessments of music teachers for the determination of correlations in criteria depending on the grade, Mean Ranks, positive dynamics is observed. Such correlations may have occurred due to the teachers' assessment of self-expression from professional aspect, taking into consideration the requirements of the national basic education standard and subject standards.

Kruskal-Wallis $\mathrm{H}$ test has been applied for the determination of correlations for criteria depending on the pupils grade (Tab. 3). Analysing the results of the questionnaire regarding the assessment of the criterion "Emotional activity", maximally significant correlations $(p=0.000)$ in all the groups of the respondents were observed. In the assessment of the criterion "Intellectual activity", maximally significant correlation is observed among pupils $(p=0.000)$, their parents $(p=0.000)$, and very significant correlations $(p=0.001)$ are observed among the music teachers. In the assessment of the criterion "Social activity", maximally significant correlations are observed among the class teachers $(\mathrm{p}$ $=0.000)$ and very significant correlations $(\mathrm{p}=0.001)$ are observed among the pupils.

Table 3

Criteria assessment for the determination of the age-dependant correlation

\begin{tabular}{lccc} 
& Emotional action & Intellectual activity & Social activity \\
\hline Pupils & $\mathrm{p}=0.000$ & $\mathrm{p}=0.000$ & $\mathrm{p}=0.001$ \\
\hline Parents & $\mathrm{p}=0.000$ & - & - \\
\hline Music teachers & $\mathrm{p}=0.000$ & $\mathrm{p}=0.001$ & - \\
\hline Class teachers & $\mathrm{p}=0.000$ & $\mathrm{p}=0.000$ & $\mathrm{p}=0.000$ \\
\hline
\end{tabular}

Source: own research

Analysing Mean Rank values for all maximally significant correlations $(p=0.000)$ and for the determination of correlation depending on the pupils' age ( $p=0.0001)$, it is obvious that Rank Mean dynamics does not differ from the dynamics of determination of criteria correlations depending on the pupils grade. It indicates that pupils of appropriate age study in each grade.

The obtained results provide an opportunity to analyse each criterion and its characteristic indicators separately for all the respondents: depending on gender, age and grade.

The criterion "Social activity" is analysed in detail within the framework of the article.

In assessments of social activity, depending on the respondents group (Kruskal-Walis test), maximally significant correlations $(\mathrm{p}=0,000)$ are observed. Social activities are most highly assessed by class teachers (Mean 
Rank 2212,43) associating it with cooperation and communication within the class, while the lowest assessment is among the pupils (Mean Rank 1856,71).

Analysing the social activity assessment using Kendall rank correlation test, it can be seen that there is a maximally significant correlation between the assessment of the criterion "Social activity" and the gender of a pupil ( $\mathrm{r}=-0,173$, $\mathrm{p}=0,000)$ (Tab. 4).

Table 4

Correlation between criterion "Social activity" assessment and pupils gender

\begin{tabular}{lccc} 
& Parents & Music teachers & Class teachers \\
\hline Pupils & $\mathrm{p}=0.030$ & $\mathrm{p}=0,005$ & $\mathrm{p}=0,000$ \\
\hline Parents & - & - & $\mathrm{p}=0,000$ \\
\hline Music teachers & - & - & $\mathrm{p}=0,000$ \\
\hline
\end{tabular}

Source: own research

The correlations in the assessment of social activity depending on the grade may have arisen because pupils now tend to have versatile interests. Pupils become independent, make decisions on activities to engage in and express themselves in various ways on their own.

Pupils perceive social activities during lessons as not so significant. The most significant correlations in the assessment of the criterion "Social activity" depend on the gender (Mean Rank 1972.81 for boys, Mean Rank 2093.63 for girls). Girls of primary school age are socially more active, they like to participate in the organisation of class activities, which explains the correlations in the assessment of social activity criterion.

The assessment of the criterion "Social activity" by the respondents indicate how significant the activity cooperation and interaction in music are. This indicates the pupils' sense of belonging to a group and readiness to take initiative, as well as the openness to the variety in the culture in music.

Analysing the cooperation experience, pupils state that they like to sing with friends (102 responses), yet only 43 agree that they take initiative willingly. The obtained results confirm that pupils fear to express themselves, express their opinion and take responsibility for music practising process. The music teachers' assessment of the statements "Take initiative in creative activities" and "Like to teach friends" confirm the passive character of pupils' self-expression (Fig. 2).

The criterion "Social activity" includes the indicators, which statements' assessments determine activity in musical ensemble, skill to take initiative and responsibility for ones own activity in musical ensemble and cooperation with friends and mates. 


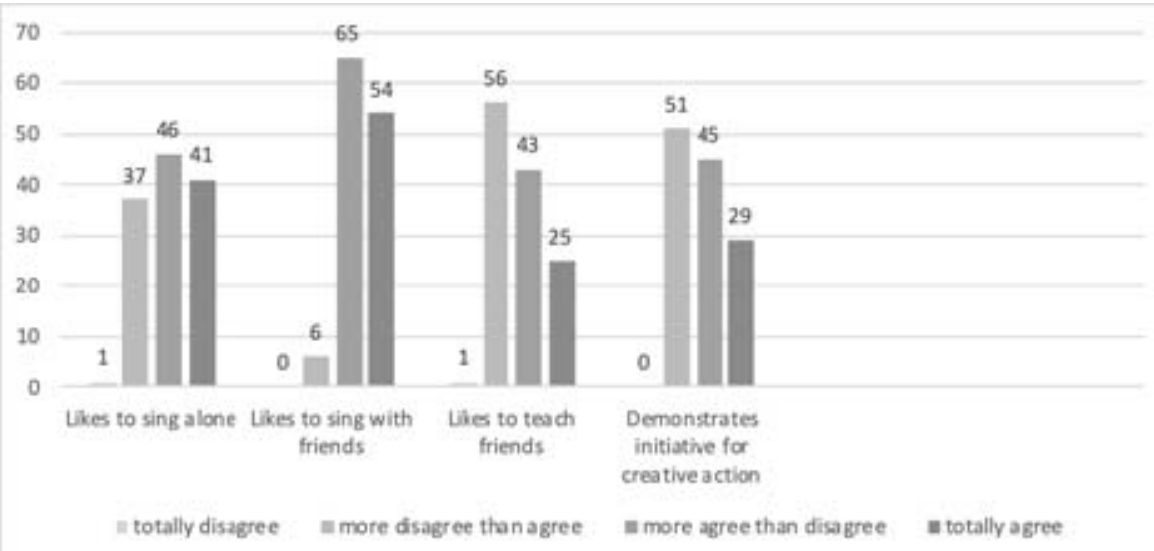

Figure 2

Correlation between criterion "Social activity"

indicators in music teachers' opinions

Source: own research

The development of self-expression skills in relation to participation in musical ensembles is considered significant and very significant by $64 \%$ of pupils, $72,7 \%$ of parents, $69,1 \%$ of music teachers, $73,4 \%$ of class teachers. $30 \%$ of music teachers disagree with social activity implementation in music education. Such difference may have occurred because music teachers consider participation in school's musical ensembles significant, without separating social activity. Activities in school's musical ensembles is perceived as a component of intellectual activity, while music teachers associate social activities with pupils' participation in out-of-school musical ensembles. Analysing the results obtained, it is concluded that pupils' parents and class teachers perceive participation in musical ensembles as significant, as it promotes pupils' socialization in a managed environment, where there are less chances to be negatively influenced by friends.

The obtained assessment confirms pupils' activity in music practising processes in ensembles. Yet, $17,1 \%$ of pupils state that participation in musical ensembles is no longer relevant. Such assessment is related to pupils' social activity and indicates pupils' unwillingness to cooperate and participate in musical ensembles, the reason for which might be the lack of experience in such activities. It is possibly based on previous negative experience, received criticism, rejection by peers or disinterestedness of parents.

\section{CONCLUSIONS}

Self-expression in social aspects is important for pupils: it is related to the socialisation in microenvironment (family) and macroenviron- 
ment (with friends) and affects social cooperation and emotional aspect of communication.

Empirical research data analysis leads to a conclusion that an important aspect of the development of self-expression skill is the social performance criterion on which a pupil's need for self-expression in a social environment of practising music is based.

Analysing age and gender-based correlations in the assessment of the self-expression skill criterion "Social activity", it can be concluded that with age pupils become more independent and engage in music-related social activities more often. Girls are socially more active and emotional and engage in artistic activities more often. Pupils' self-expression skills related to social activity is most significant according to the parents, as self-expression in music stimulates a child's intellectual development, the integration in social and cultural environment, and helps to develop communication in family, which parents considered to be a significant factor influencing the child's growth.

The research confirms the role of teachers in the development of pupil's self-expression skills, promoting integration of formal and informal learning processes and transformation in formal and informal learning environment. The content of music teaching must be linked with various forms of art, providing pupils with an opportunity to express their individuality according to their abilities and interests. Pupils broaden their horizons and develop new self-expression experience.

\section{REFERENCES}

[1] Baacke, D. (2007). Medienpädagogik [Media Education]. Tübingen: Niemeyer.

[2] Barrett, M.S. (2011). Towards a cultural psychology of music education. In M.S. Barrett (Ed.), A cultural psychology of music education Oxford University Press (pp. 1-15). Oxford, U.K.: Oxford University.

[3] Ben-Eliyahu, A. (2019). Academic Emotional Learning: A critical component of self-regulated learning in the emotional learning cycle. Educational Psychologist, 54(2), 84-105. https://doi. org/10.1080/00461520.2019.1582345

[4] Bronfenbrenner, U. (1994). Nature-Nurture reconceptualized in developmental perspective: A bioecological model. Psychological Review, 101(4), 568-86. doi:10.1037/0033-295x.101.4.568

[5] Bruner, J.S. (1996). The Culture of Education. USA: President and Fellows of Harward College.

[6] Burdjē, P. (2004). Praktiskā jēga [Practical sense]. Rīga: Omnia Mea.

[7] Cross, I. (2001). Music, cognition, culture, and evolution. Annals of the New York Academy of Sciences, 930, 28-42. doi: 10.1111/j.1749-6632.2001.tb05723.x

[8] Fletcher, T. (2020). The Extended Extended Family: Sport and Familial Relationships. Palgrave Macmillan, Cham.

[9] Hall, P., \& Lamont, M. (Eds.). (2009). Successful societies: How institutions and culture affect health. Cambridge, UK: Cambridge University Press.

[10] Howard, K. (2018). The Emergence of Children's Multicultural Sensitivity: An Elementary School Music Culture Project. Journal of Research in Music Education, 66(3), 261-277. Retviered from https://journals.sagepub.com/toc/jrm/66/3

[11] Huron, D. (2001). Is music an evolutionary adaptation? Annals of the New York Academy of Sciences, 930, 43-61. doi: 10.1111/j.1749-6632.2001.tb05724.x

[12] Kepule, I., Strode, A. (2019). Formation of pupils' music learning experience and self-expression skills in socio-emotional activities. In V.Lubkina (ed.), Sabiedriba, Integrācija, Izglìtiba: 
Starptautiskās zinātniskās konferences materiäli" (244.-254.lpp.). Latvija, RTA, ISSN 1691-5887 DOI: http://dx.doi.org/10.17770/sie2019vol2.4003

[13] Kristapsone, S. (2008). Zinātniskā pētnieciba studiju procesā [Scientific research in the study process]. Rìga: Turība

[14] Pavlou, V. (2019). Art Technology Integration: Digital Storytellying as a Transformative Pedagogy in Primary Education. The International Journal of the ArtEDesign Education. https://doi. org/10.1111/jade.12254

[15] Piaget, J. (1961). The Child's Conception of Number. London: Routledge and Kegan Paul Ltg.

[16] Popers, K. (2005). Nākotne atvērta [The future is open]. Rīga: Zvaigzne ABC.

[17] Reybrouck, M., Eerola, T., \& Podlipniak, P. (Eds.). (2018). Music and the Functions of theBrain: Arousal, Emotions, and Pleasure. Lausanne: Frontiers Media. doi:10.3389/978-2-88945-452-5

[18] Roger, C.R. (1969). Freedom to Learn. A View of What Education Migh Become. Columbus, Ohio: Charles E. Merrill publishing Company.

[19] Rubene, Z. (2011). Bèrns un jaunietis digitālajā pasaulē [Children and young people in the digital world]. Zinātniski metodisks izdevums „TAGAD”. ESF projekta „Atbalsts valsts valodas apguvei un bilingvālajai izglitīibai" Nr. 2008/0003/1DP/1.2.1.2.1/08/IPIA/VIAA/002 izdevums.

[20] Schäfer, K., \& Eerola, T. (2018). How listening to music and engagement with other media provide a sense of belonging: An exploratory study of social surrogacy. Psychology of Music. https:// doi.org/10.1177/0305735618795036

[21] Schorb, B. (2005). Medienforschung. In: Grundbegiffe Medienpädagogik. [Media research. In: Basic concepts of media education.]. München: Kopaed.

[22] Shanker, S., Bertrand, J., (2013). Self-Regulation... What is it and why is it important for learning? Uploaded by the Government of British Columbia's official channel on YouTube, on December 02 2013. https:/ / youtu.be/ eyyV8Tylcms

[23] Siegel, D. (2010). Self-Regulation: Strategies for Home and School. Recorded January 12, 2010 Accessed on Nov 7 2012, upladed by Steindhardt School at NYU, official YouTube channel.

[24] Smits, E. (2000). Paātrinătā mācišanāas klasē [Accelerated classroom learning]. Rìga: Pètergailis.

[25] Spanhel, D. (2006). Medienerziehung. Band 3. Erziehungs - und Bildungsaufgaben in der Mediengesellschaft [Media Education. Volume 3. Upbringing and educational tasks in the media society]. Stuttgart: Klett - Cotta.

[26] Svence, G. (1999). Attīstïbas psiholoğija [Developmental psychology]. Rīga: Zvaigzne ABC.

[27] Vuorinens, R., \& Tūnala, E. (1999). Cilvēka attīstïba posmi [Stages of human development]. Rìga: Zvaigzne ABC.

[28] Wright, R. (2016). Informal Learning in General Music Education. In C. Abril, C, Gault (Eds.), Teaching General Music: Approaches, Issues, and Viewpoints. New York: Oxford University Press. DOI: https://dx.doi.org/10.1093/acprof:oso/9780199328093.003.0011

[29] Žogla, I. (2001). Skolēnu izzinasas attieksme un tās veidošanās mācību procesā [Pupils' cognitive attitude and its formation in the study process]. Rīga: RaKa. 